INVENTORY:Jurnal Akuntansi

ISSN 2597-7202 (Print); ISSN 2613-912X (Online)

Vol. 5, No. 2, Oktober 2021, Hal 101-113

Tersedia Online: http://e-journal.unipma.ac.id/index.php/inventory

\title{
Model Penerapan Akad Transaksi Syariah Pada BUMDes Pengalangan Sejahtera Dalam Masyarakat Pluralisme
}

\author{
Fira Kartika Ningtyas ${ }^{1}$, Rohmawati Kusumaningtias ${ }^{2 *}$ \\ Progam Studi Akuntansi, Universitas Negeri Surabaya, Indonesia \\ email: firakartikan@gmail.com ${ }^{1}$; rohmawatikusumaningtias@unesa.ac.id ${ }^{2}$
}

\begin{abstract}
Abstrak
Penelitian ini bertujuan untuk mengetahui model penerapan akad-akad transaksi syariah berdasarkan Fatwan DSN MUI dan SAK Syariah pada BUMDes Pengalangan Sejahtera. Penelitian ini juga menjelaskan terkait penerapan transaksi syariah dalam masyarakat pluralisme untuk mengetahui pemahaman serta minat dari masyarakat untuk menjadi nasabah bank desa yang berprinsip syariah. Metode yang digunakan pada penelitian ini ialah metode kualitatif deskriptive dengan data sekunder dan primer. Pengumpulan data pendukung dilakukan dengan studi lapangan melalui wawancara, observasi dan dokumentasi. Hasil penelitian ini menunjukkan bahwa penerapan akad pada transaksi BUMDes belum sesuai dengan Fatwa DSN MUI dan SAK Syariah, sehingga peneliti memberikan hasil berupa model penerapan akad syariah sesuai dengan macam-macam jenis produk pembiayaan yang diterapkan oleh bank desa pada BUMDes Pengalangan Sejahtera. Secara umum ketidaksesuaian SAK Syariah terletak pada penyusuan laporan keuangan BUMDes yang tidak adanya pebeda antara pengakuan, pengukuran, penyajian, dan pengungkapan. Sedangkan sesuai Fatwa DSN MUI ketidaksesuaian terletak dari beberapa ketentuan yang berlaku.
\end{abstract}

Kata kunci: Akad-akad Syariah; Fatwa DSN MUI; SAK Syariah; Pluralisme.

The Model Of Sharia Transaction Contracts Implementation in BUMDes Of Pengalangan Sejahtera In A Pluralism Society

\begin{abstract}
This research aim to determine the implementation model of sharia transaction contracts based on Fatwan DSN MUI and SAK Syariah at BUMDes Pengalangan Sejahtera. This study explain the application of sharia transactions in a pluralistic society to find out the understanding and interest of the community become a customer of a village bank based on sharia principles. The method used in this research is descriptive qualitative method with secondary and primary data. Supporting data collection was carried out by field studies through interviews, observation and documentation. The results of this study indicate that the implementation of the contract on BUMDes transactions is not in accordance with the Fatwa of the MUI and SAK Syariah DSN, so the researchers provide results in the form of a sharia contract implementation model in accordance with the various types of financing products applied by village banks to BUMDes Pengalangan Sejahtera. In general, the non-conformity of SAK Syariah lies in the preparation of BUMDes financial statements where there is no difference between recognition, measurement, presentation and disclosure. Meanwhile, according to the MUI DSN Fatwa, the non-conformity lies in several applicable provisions.
\end{abstract}

Keywords: Sharia contracts; Fatwa DSN MUI; Islamic SAK; Pluralism.

DOI: 10.25273 /inventory.v5vi2i.9519

Copyright (C) 2021 Penulis

Sume rights reserved. 


\section{Pendahuluan}

Pendahuluan Pemerintah Indonesia dalam mengoptimalkan perekonomian di desa membutuhkan dukungan atau kerja sama dari pemerintah daerah, perangkat desa, dan seluruh masyarakat. Dukungan tersebut dapat dilaksanakan dengan melakukan pemerataan ekonomi dimulai dari daerah terpencil atau dapat disebut daerah pedesaan. Pemerintah desa memiliki tugas untuk memberikan kesejahteraan masyakarat serta meningkatkan Pendapatan Asli Daerah (PAD) agar bermanfaat menjadi penggerak ekonomi daerah. Faktor - faktor yang dapat mensejahterakan masyarakat desa ialah perangkat desa mampu memanfaatkan potensi-potensi yang terdapat dalam desa, pengadaan pelayan pendidikan dan kesehatan, memberikan fasilitas untuk memenuhi keperluan rumah tangga, dan menyediakan lapangan pekerjaan untuk masyarakat desa. Meningkatkan kesejahteraan masyarakat desa bertujuan untuk mengembangkan ide-ide kreatif dari masyarakat serta memunculkan rasa kerja sama dan kebersamaan antara perangkat desa dengan masyarakat (Nurohman, Yulfan Arif, Qurniawati, 2019).

Optimalisasi perekonomian desa dapat berupa penyesuaian berdasarkan UU No. 32 Tahun 2004 Pasal 213 ayat (1) mengungkapkan bahwa pemerintah daerah memberikan kebebasan perangkat desa untuk mendirikan Badan Usaha Milik Desa (BUMDes) yang sesuai dengan kemampuan dari masyarakat desa sebagai pihak pengelola BUMDes. Masyarakat perlu dikembangkan melalui kegiatan pemberdayaan dengan pembahasan topik-topik yang dapat menunjang keberlangsungan usaha pada BUMDes. Pemberdayaan ini bertujuan untuk memotivasi masyarakat agar memiliki kesadaran dengan potensi yang dimiliki dan dapat mengembangkan potensi tersebut untuk menciptakan BUMDes yang dapat dipertanggung jawabkan pada pihak eksternal. Pertanggung jawaban BUMDes untuk pihak eksternal dapat berupa laporan keuangan yang telah disusun oleh pengurus BUMDes dari berbagai macam unit usaha yang dimiliki. Irawati \& Martanti (2017) laporan keuangan dapat bermanfaat sebagai pengambilan keputusan ketika BUMDes akan mendirikan suatu unit usaha, dikarenakan dalam mendirikan suatu unit usaha akan membutuhkan dana sehingga laporan keuangan dapat menjadi tolak ukur mampu atau tidak BUMDes dalam mendirikan unit usaha baru.

Puwari (2010) memperkuat bahwa tujuan laporan keuangan selain sebagai pengambilan keputusan dapat menghasilkan informasi terkait sumber daya ekonomi yang dimiliki suatu lembaga. Dalam penyusunan laporan keuangan dapat menerapkan standar akuntansi keuangan yang berlaku agar menghasilkan laporan keuangan yang transparan dan terpercaya. Kondisi di desa dapat menentukan penerapan transaksi pada BUMDes, jika tujuan BUMDes untuk mensejahterakan masyarakat desa maka transaksi yang selaras diterapakan ialah transaksi syariah. Hal ini dikarenakan dalam transaksi syariah mengutamakan prinsip kesejahteraan dan keadilan untuk masyarakat serta BUMDes dapat memberikan dukungan hanya pada kegiatan yang diperbolehkan berdasarkan syariat Islam. Pengertian ekonomi Islam pada penelitian Wildan (2018) mengungkapkan bahwa kegiatan usaha yang dijalankan oleh suatu individu atau kelompok pada badan usaha yang memiliki badan hukum atau tidak berbadan hukum, dalam kegiatan yang bersifat komersil ataupun tidak komersial dengan berlandaskan prinsip syariah sesuai Al-Qur'an dan As- sunnah.

Pada transaksi syariah terdapat berbagai macam akad bertujuan untuk menciptakan penerapan transaksi syariah sesuai dengan aturan yang berlaku. Akad ialah suatu kesepakatan atau perjanjian yang dilakukan secara ijab kabul, dengan adanya kedua belah pihak yang bersangkutan dalam menyepakati akad terkait hak dan kewajiban yang menunjang terlaksanakannya produk-produk syariah sesuai dengan peraturan. Akad hanya dapat diterapkan pada kegiatan tertentu berdasarkan pada syariat Islam dengan adanya keridhoan dari seluruh pihak. Menurut Fatwa Dewan Syariah Nasional Majelis Ulama Indonesia No: 19/DSNMUI/IV/2001 menjelaskan bahwa prinsip akad qardh yaitu suatu akad yang diterapkan untuk transaksi pembiayaan antara pihak bank kepada nasabah dengan ketentuan dana pembiayaan 
yang diberikan nasabah wajib dikembalikan kepada pihak bank sesuai nominal yang telah dipinjamkan dan adanya kesepakatan waktu untuk pelunasan. Pada penerapan akad qardh ini tidak mengambil keuntungan dari nasabah saat melakukan pembiayaan ke bank, dapat diartikan bahwa akad qardh tidak mengharapkan imbalan yang diberikan oleh nasabah. Terdapat dua macam akad qardh yang telah dijelaskan oleh Fatwa Dewan Syariah Nasional Majelis Ulama Indonesia No: 79/DSN MUI/III/2011. Akad qardh dapat berdiri sendiri dengan tujuan sosial dan akad qardh bukan termasuk produk yang mendapatkan keuntungan. Pada akad qardh dengan tujuan sosial yaitu melakukan transaksi pembiayaan dengan cara membantu antara sesama masyarakat tanpa mengharapkan imbalan untuk kegiatan sosial masyarakat.

Menurut Muhayatsyah (2019) pada penelitiannya menjelaskan bahawa akad ijarah adalah akad sewa menyewa dalam bentuk barang dan jasa, tanpa adanya pemindahan hak milik barang tersebut, dikarenakan barang dan jasa yang disewakan tetap menjadi hak milik yang menyewakan. Metode transaksi akad ijarah terdapat dua macam yaitu Ijarah dan Al Ijarah al Muntahiya bit Tamlik (IMBT), pada penerapannya IMBT terdapat beberapa perbedaan dari akad ijarah. IMBT merupakan akad yang diterapkan pada sewa menyewa dengan adanya perjanjian kontrak jual beli jika diperlukan, sehingga diakhir masa sewa barang persewaan tersebut menjadi hak milik dari penyewa. Sedangkan, akad ijarah ialah akad sewa menyewa tanpa adanya perpindahan kepemilikan di akhir sewa. Akad murbahah ialah suatu akad jual beli yang berlandaskan kepercayaan antara penjual dan pembeli. Pada akad murabahah ini penjual dalam menjual barang dagangannya kepada pembeli di awal sebelum terjadinya transaksi memberikan informasi terkait harga perolehan awal dan keuntungan yang didapatkan dalam penjualan barang tersebut. Hal ini juga diperkuat oleh Pratiwi, Dini, Nawawi, M. Kholil (2015) mengungkapkan bahwa akad murabahah ialah transaksi berdasarkan kepercayaan, hal ini pembeli memberikan kepercayaan kepada penjual dalam menentukan harga jual barang untuk dibelinya.

Akad wadi'ah dalam penerapannya, jika nasabah membutuhkan dana simpanan secara bebas nasabah dapat mengambil tanpa ada persyaratan khusus dan imbalan yang ditentukan. Pramesty (2020) menyampaikan bahwa terdapat dua macam akad wadi'ah yaitu, akad wadi'ah yad al-amanah dan akad wadi'ah yad ad-dhamanah, pihak yang dititipkan tidak diperbolehkan menggunakan dan mengambil manfaat dari barang dan dana yang diberikan oleh pihak yang menitipkan sehingga pihak yang dititipkan wajib menjaga kesepakatan simpan barang atau dana penjelasan ini disebut akad wadi'ah yad al-amanah. Sedangkan, akad wadi'ah yad addhamanah ialah pihak yang dititipkan diperbolehkan mendapatkan manfaat dan menggunakan barang atau dana sesuai dengan kesepakatan kedua pihak.

Pembiayaan dengan akad mudharabah diatur pada Fatwa Dewan Syariah Nasional Majelis Ulama Indonesia (No: 115/DSN-MUI/IX/2017) dengan penjelasan bahwa akad mudharabah ialah suatu kesepakatan yang dilakukan oleh kedua pihak antara bank desa dengan nasabah desa. Pada pembiayaan ini bank desa selaku pemilik modal atau penyedia modal dan nasabah selaku pelaku usaha untuk mengelola modal atau dana yang diberikan oleh bank desa dalam bentuk benda maupun orang. Terdapat empat bentuk akad mudharabah yang dapat diterapkan yaitu, 1) Mudharabah - muqayyadah ialah akad yang diterapakan oleh pemilik modal dengan memberikan batasan terkait jenis usaha, waktu dan tempat usaha, 2) Mudharabah - muthlaqah ialah akad yang penerapannya memberikan kebebasan pada pengelola modal terkait jenis usaha, waktu, dan tempat usaha, 3) Mudharabah - tsuna'iyyah ialah akad yang diterapkan ketika bank desa dan nasabah desa melakukan usahanya secara langsung setelah kesepakatan, 4) Mudharabah - musytarakah ialah akad yang diterapkan ketika pemilik usaha atau pengelola modal juga ikut serta memberikan dukungan modal pada usahanya. Selanjutnya, akad wakalah bi al-ujrah menjelaskan bahwa suatu lembaga keuangan syariah saat melakukan proses transaksi dengan pihak ketiga jika mengalami keterbatasan dalam sumber daya manusia yang melayani proses tersebut, dapat diperbolehkan adanya suatu wakil. Wakil tersebut dapat 
berupa orang dengan surat kuasa untuk aktivitas berbadan hukum ataupun tidak berbadan hukum. Terdapat pengertian yang berbeda antara akad wakalah dan akad wakalah bi al-ujrah. Akad wakalah ialah akad yang diterapkan oleh suatu lembaga keuangan syariah dalam hal memberikan kekuasaan kepada seseorang untuk menjalankan suatu kegiatan dalam hal perbuatan hukum maupun tidak berbadan hukum. Sedangkan, akad wakalah bi al-ujrah ialah akad yang penerapannya sama seperti akad wakalah tetapi dalam pemberian kuasa disertai dengan adanya fee diakhir akad untuk pihak penerima kuasa.

Desa Pengalangan merupakan salah satu desa di Kecamatan Menganti, Kabupaten Gresik, Provinsi Jawa Timur. Desa Pengalangan termasuk desa berkembang yang telah mendirikan BUMDes pada tahun 2016 tepat pada tanggal 02 April 2016 sesuai dengan Peraturan Desa No. 3 Tahun 2016. BUMDes tersebut diberi nama BUMDes Pengalangan Sejahtera. Pada kegiatan operasional BUMDes ini memiliki tiga unit usaha ialah unit usaha bank desa, unit usaha pembayaran online, dan unit usaha pasar desa. Berdasarkan hasil wawancara awal dengan Direktur BUMDes, dijelaskan bahwa kehidupan masyarakat Desa Pengalangan memiliki berbagai macam kepercayaan yang dianut oleh masyarakat desa. Mayoritas dari kepercayaan masyarakat desa paling utama ialah agama Islam, kedua agama Hindu, dan ketiga agama Budha. Dari berbagai macam kepercayaan masyarakat desa dapat saling menghargai dan toleransi antara sesama dalam menjalankan kewajiban beribadah di tempat peribadahan masing-masing. Perbedaan dari kepercayaan yang dianut oleh masyarakat desa dapat dikatakan sebagai pluralisme. Ma'arif (2018) pluralisme ialah suatu prinsip yang wajib ditanamkan pada diri individu untuk saling menghormati, memahami, dan mengerti terjadinya perbedaan untuk tercapainya masyarakat yang rukun dan damai antar umat beragama.

Pada unit usaha bank desa BUMDes Pengalangan Sejahtera ini menerapkan akad transaksi syariah untuk nasabah, akad yang telah diterapkan yaitu akad qardh, akad ijarah, akad mudharabah, dan akad murabahah. Pada penerapan akad qardh peneliti mendapatkan penjelasan dari Direktur BUMDes sebagai berikut:

"Penerapan akad qardh kami berdampingan dengan akad ijarah, ketika nasabah mengajukan permohonan peminjaman dana kepada bank desa, nasabah wajib memberikan jaminan kepada bank desa, jaminan tersebut berdasarkan akad ijarah bank memberikan sewa tempat untuk penyimpanan jaminan. Sewa tempat untuk jaminan tersebut sebesar $1 \%$ dari nominal pembiayaan yang diajukan oleh nasabah." (Direktur BUMDes).

Berdasarkan dari penjelasan Direktur BUMDes tersebut dapat disimpulkan bahwa penerapan akad qardh pada bank desa BUMDes Pengalangan Sejahtera belum sesuai dengan Fatwa Dewan Syariah Nasional MUI dan SAK Syariah yang berlaku. Hal ini dikarenakan akad qardh dan akad ijarah mempunyai perbedaan tujuan dan penggunaan. Maka secara teoritis, penelitian ini bermanfaat untuk menciptakan skema model penerapan akad transaksi Syariah pada BUMDes Pengalangan Sejahterah sesuai dengan SAK Syariah dan Fatwa Dewan Syariah Nasional MUI. Sedangkan, secara praktis, penelitian ini secara praktik bermanfaat untuk penerapan transaksi pada unit usaha bank desa yang telah sesuai dengan standar yang berlaku, sehingga pengelolaan bank desa di masa mendatang dapat dipertanggung jawabkan kepada pihak eksternal secara transparan tanpa diragukan.

\section{Metode Penelitian}

Penelitian ini dilaksanakan pada BUMDes Desa Pengalangan, Kecamatan Menganti, Kabupaten Gresik, Provinsi Jawa Timur. Waktu penelitian di mulai pada bulan Oktober 2020. Metode penelitian yang digunakan ialah metode kualitatif. Metode kualitatif ialah metode yang digunakan dalam sebuah penelitian secara langsung untuk mengamati suatu proses fenomena atau kondisi yang terjadi pada lapangan. Nugrahani (2014) mempertegas bahwa metode 
kualitatif ialah dipergunakan untuk jenis penelitian yang temuan tanpa bantuan statistik, karena penelitian ini mengamati fenomena yang terjadi secara langsung pada kasus yang diteliti. Peneliti lebih menentukan menggunakan metode kualitatif dengan dasar bahwa penelitian ini akan membahas fenomena terkait penerapan akad-akad transaksi syariah pada BUMDes Pengalangan Sejahtera, maka jika peneliti menggunakan metode kuantitatif kurang tepat untuk menggali informasi pada lokasi.

Sumber data pada penelitian ini menggunakan data primer dan data sekunder yang kedua sumber data tersebut saling berhubungan untuk melengkapi informasi dalam menyelesaikan permasalahan. Terdapat sumber data utama pada penelitian ini ialah data primer. Menurut Nugrahani (2014) data primer pada penelitian kualitatif diterapkan untuk menggali informasi lebih rinci dengan teknik wawancara dan observasi. Data tersebut didapatkan dari penelitian secara langsung melalui wawancara kepada narasumber yang dituju sesuai dengan fokus penelitian. Sedangkan, data sekunder ialah data yang didapatkan secara tidak langsung. Data tersebut dapat berupa sebuah dokumentasi, literatur, laporan keuangan yang berhubungan dengan permasalahan penelitian. Penelitian ini menggunakan data sekunder meliputi, data nasabah, laporan keuangan, prosedur penerapan transaksi, dan berkas-berkas pendukung operasional kegiatan BUMDes Pengalangan Sejahtera. Dalam menggali informasi untuk penelitian ini membutuhkan lima responden ialah tabel 1,

Tabel 1. Daftar Nama Responden

\begin{tabular}{|c|l|l|}
\hline No. & \multicolumn{1}{|c|}{ Nama } & \multicolumn{1}{c|}{ Jabatan } \\
\hline 1. & Dodi Dirgahayu J, S.Pd & Direktur BUMDes \\
\hline 2. & Azizah & Staff BUMDes Bidang Keuangan \\
\hline 3. & Imam & Staff BUMDes Unit Usaha Bank Desa \\
\hline 4. & Sukarsih & Nasabah BUMDes \\
\hline 5 & Yeni & Masyarakat Desa \\
\hline
\end{tabular}

Sumber: Hasil Data Penelitian

Berdasarkan sumber data yang telah ditentukan oleh peneliti, maka dalam mendapatkan informasi tersebut peneliti mampu membedakan subjek dan objek penelitian agar mendapatkan hasil yang akurat. Subjek pada penelitian ini ialah pengurus BUMDes dan nasabah bank desa, sedangkan objek penelitian ini fokus pada pokok permasalahan ialah pemahaman penerapan akad-akad transaksi syariah. Penelitian ini menentukan tempat penelitian pada BUMDes Pengalangan Sejahtera dikarenakan terdapat beberapa hal pendukung, yaitu:

1. BUMDes yang mampu menerapkan prinsip syariah pada unit usaha bank desa dalam kegiatan operasional, walaupun dalam lingkup masyarakat pluralisme akan tetapi masyarakat dapat menerima ketentuan-ketentuan yang berlaku

2. BUMDes yang dapat menwujudkan kesejahteraan masyarakat dan memiliki perkembangan drastis dari berbagai macam unit usaha yang dimiliki

3. Memiliki ide-ide kreatif dan inovatif dalam mendirikan unit usaha dan tetap menerapkan prinsip syariah di setiap kegiatan.

Analisis data dilakukaan secara bersamaan dengan proses pengumpulan data. Dikarenakan analisis data ini bertujuan untuk menganalisis data yang diperoleh peneliti saat dilapangan dapat dipahami dan memberikan solusi dari permasalahan yang terjadi. Analisis data yang diterapkan oleh peneliti ialah analisis interaktif. Nugrahaningsih, Putri, Falikhatun,Winarna (2016) mengungkapkan bahwa analisis data interaktif memiliki empat langkah untuk memberikan hasil penelitian yang optimal. Langkah analisis data tersebut mulai dari pengumpulan data, reduksi data, penyajian data, dan penarikan kesimpulan.

Pengumpulan data ini meliputi data primer dan data sekunder. Data primer diperoleh dari responden ketika peneliti mengajukan pertanyaan terkait prosedur penerapan transaksi syariah pada BUMDes dan data sekunder diperoleh untuk mendukung hasil data primer terkait kesepakatan akad-akad transaksi syariah. Saat peneliti melakukan pengumpulan data pada 
analisis reduksi ini berupa kerangka pertanyaan yang akan diajukan ke responden, saat wawancara dilapangan peneliti membuat rangkuman atau catatan memo terkait informasi yang diberikan oleh responden. Saat penyajian data peneliti memastikan bahwa seluruh data yang telah dikumpulkan dapat memberikan solusi permasalahan yang terjadi. Pada penelitian ini, peneliti telah mengetahui akad-akad transaksi syariah yang telah diterapkan, kemudian peneliti melakukan perbandingan prosedur penerapan kondisi dilapangan dengan ketentuan peraturan. Jika terjadi ketidaksesuaian maka peneliti diharapkan mampu memberikan solusi berupa model untuk penerapan akad-akad transaksi syariah tersebut sesuai dengan peraturan. Pada kesimpulan peneliti dapat menyajikan mulai dari rumusah masalah yang terjadi, pengumpulan data sesuai dilapangan, serta penyelesaian masalah berupa model penerapan akad-akad transaksi syariah yang telah diterapkan sesuai pada BUMDes Pengalangan Sejahtera.

\section{Hasil dan Pembahasan}

Hasil Penelitian ini dilaksanakan pada Badan Usaha Milik Desa Pengalangan Sejahtera yang berada pada Jalan Pengalangan No. 390 RT. 06 RW. 03 Desa Pengalangan, Kecamatan Menganti, Kabupaten Gresik. BUMDes berupaya menciptakan unit usaha bank desa yang bermanfaat untuk menstabilkan perekonomian masyarakat desa dengan cara membantu menghimpun dana dan melakukan simpan pinjam dana yang dikelola dari masyarakat untuk masyarakat. Bank desa menerapkan prinsip syariah pada setiap transaksi yang dilakukan, alasan dasar untuk menerapkan prinsip syariah dilingkungan masyarakat pluralisme yaitu dari segi visi dan misi BUMDes yang mengutamakan religiusitas, amanah, sehat, dan menjadi lembaga usaha yang mandiri. Sebagaimana penjelasan dari Direktur BUMDes berikut ini,

"Saya pribadi terkait dengan akidah dan visi misi BUMDes. Itu karena di keyakinan kami walaupun tidak sama, ada yang mengatakan riba itu tidak haram, tetapi kalau saya menyakini kalau itu haram. Sehingga kami sampaikan dengan pengurus yang lain, lalu memberikan solusi untuk menerapkan bisnis sambil menerapkan prinsipprinsip syariah. Kami mungkin tidak bisa menerapkan 100\% tetapi mana yang bisa dulu diterapkan kita terapkan sambil bertahap." (Direktur BUMDes)

Penjelasan dari direktur BUMDes mengutarakan bahwa seluruh pengurus BUMDes percaya dan yakin dengan menerapkan prinsip syariah pada unit usaha bank desa dapat mengarahkan perekonomi desa lebih baik daripada penerapan ekonomi konevensional. Dikarenakan BUMDes hadir untuk membantu perekonomian masyarakat sehingga dengan prinsip syariah selaras dengan tujuan BUMDes untuk memberikan pelayanan dan mempermudah masyarakat untuk melakukan aktivitas yang membutuhkan pendanaan khususnya dan menghidari adanya kegiatan yang tidak seharusnya terjadi sesuai kaidah Islam. Bank desa memberikan pelayanan jenis - jenis produk syariah yang telah disepakati oleh seluruh pengurus BUMDes secara bertahap untuk meningkatkan minat masyarakat berpartisipasi di bank desa serta memakmurkan kehidupan masyarakat desa, berikut ini produk - produk yang diterapkan pada bank desa tabel 2,

Tabel 2. Jenis - Jenis Produk Bank Desa BUMDes Pengalangan Sejahtera

\begin{tabular}{|l|l|}
\hline No. & \multicolumn{1}{|c|}{ Produk } \\
\hline 1. & Tabungan: \\
& a. Tabungan Umum \\
& b. Tabungan Pendidikan \\
& c. Tabungan Qurban \\
& d. Tabungan Wisata \\
\hline 2. & Deposito / Mudharabah: \\
& a. 1 Bulan \\
& b. 3 Bulan \\
& c. 6 Bulan \\
\hline
\end{tabular}




\begin{tabular}{|l|l|}
\hline & d. 12 Bulan \\
\hline 3. & $\begin{array}{l}\text { Pembiayaan: } \\
\text { a. Akad Qardh } \\
\end{array}$ \\
b. Akad Murabahah \\
\hline 4. & PPOB (Payment Poin Online Bank) \\
\hline
\end{tabular}

Sumber: Dokumen Bank Desa BUMDes Pengalangan Sejahtera

Hasil yang ditemui oleh peneliti sama seperti hasil penelitian terdahulu yang dilakukan oleh Febryani et al. (2019) mengungkapkan bahwa pemerintah memberikan izin pendirian program BUMDes untuk meningkatkan dan menjamin perekonomian di desa dengan memberikan pelayanan simpan pinjam yang dapat dimanfaatkan masyarakat untuk mengembangkan usaha yang dimiliki. Simpan pinjam yang diterapkan untuk masyarakat desa perlu pertimbangan pengenaan tarif bunga cukup rendah agar masyarakat kelas bawah dapat berminat memulai bisnis untuk meningkatkan taraf hidupnya.

Pembahasan dari penelitian ini terdapat beberapa keunggulan yang dimiliki oleh bank desa, sehingga dapat mengundang partisipasi masyarakat desa untuk menjadi nasabah. Berikut keunggulan dari unit usaha bank desa ialah, 1) Jika nasabah mengajukan pembiyaan ke bank desa tidak adanya pengenaan denda apabila mengalami keterlambatan dalam melunasi pembiayaan dengan akad qardh, 2) Masyarakat terbebaskan dari adanya rentenir yang mengenakan bunga sebesar $2 \%$ setiap bulan pada pembiayaan masyarakat, 3) Dari segi pelayanan dengan adanya moblie banking, nasabah tidak mengalami kesusahan dalam melaksanakan transaksi serta dalam proses pengajuan pembiayaan bank desa melayani dengan cepat dan ramah, 4) Penerapan prinsip syariah yang berguna untuk menjamin dana yang dikelola oleh bank desa memiliki keberkahan, sehingga dapat diterima pula oleh masyarakat non-Islam.

Tingkat partisipasi masyarakat desa termasuk sebagai tolak ukur keberhasilan BUMDes dalam mewujudkan tujuan dan manfaatnya. Saat ini BUMDes Pengalangan Sejatera mengalami keberhasilan dalam meningkatkan jumlah penduduk yang berpartisipasi pada seluruh kegiatan BUMDes, dan menghargai keputusan pengurus BUMDes bahwa adanya penerapan prinsip transaksi syariah pada unit usaha bank desa. Dalam hal ini diperkuat oleh pemaparan salah satu nasabah bank desa non - Islam sebagai berikut,

"Sudah 3 tahun jadi nasabah, yang menjadi nasabah saya dan anak saya saja. Pertama kali yang menjadi nasabah saya, lalu anak saya baru tahun 2020 menjadi nasabah untuk tabungan kebutuhan pendidikan. Tertarik, karena murah daripada bank-bank lain, tidak adanya denda. Lalu pokoknya kita bisa bayar tiap bulannya gitu aja. Dan tidak adanya bunga tiap bulannya, cukup diawal kena biaya administrasi dan infaq itu." (Nasabah Bank Desa)

Penerapan transaksi syariah dapat diterima oleh nasabah bank desa, tetapi tidak semua nasabah memahami dengan sepenuhnya penerapan produk atau akad-akad yang diterapkan bank desa. Dikarenakan nasabah berfikiran bahwa selama biaya yang dikenakan cukup rendah dan dikelola oleh masyarakat desa sendiri selaku pengurus maka nasabah dapat sepenuhnya percaya oleh bank desa.

Penerapan akad murabahah pada BUMDes Pengalangan Sejahtera sebagaian besar sesuai dengan Fatwa DSN MUI dan SAK Syariah. Berdasarkan ketentuan Fatwa DSN MUI pertama sesuai dengan penerapan di bank desa yang menunjukan bahwa tidak adanya riba pada proses pelunasan atau besaran angsuran yang dikenakan kepada nasabah, hal ini terbukti dari angsuran tiap bulan yang dikenakan oleh nasabah dengan nominal yang konstan tanpa adanya perbedaan nominal pengenaan setiap bulan, tetapi terdapat jangka waktu pelunasan maximal 3 bulan. Prosedur pertama kali untuk melaksanakan kesepakatan akad murabahah ialah, nasabah dapat memberikan informasi kepada bank desa terkait bentuk barang yang dibutuhkan sehingga bank desa memperjualbelikan barang sesuai dengan syariat Islam. Jika bank desa menyetujui barang yang diperjualbelikan, maka pembiayaan 
secara keseluruhan atau sebagian dibiayai oleh bank desa sesuai kesepakatan. Bank desa berhak melaksanakan pembelian barang sesuai kebutuhan nasabah serta memberikan informasi dengan jujur terkait kualifikasi maupun harga pembelian tersebut, pada ketentuan ini bank desa Pengalangan belum menerapkan sesuai ketentuan dikarenakan proses pembelian barang bank desa memberikan kepercayaan kepada nasabah untuk mencari sesuai kebutuhan agar nasabah merasa puas dan sesuai dengan yang diinginkan.

Penyimpangan ini terjadi karena adanya kendala yaitu keterbatasan jumlah sumber daya manusia pada bank desa dan bank desa belum memiliki hubungan kerja sama dengan pihak-pihak supplier penyedia barang, dikarenakan bank desa tidak tentu mengetahui kebutuhan barang dari masing-masing nasabah. Penyimpangan ini dapat dicegah dengan cara memberikan edukasi terkait penerapan akad murabahah dan manfaatnya. Selanjutnya, BUMDes memberikan beberapa pilihan barang yang mayoritas dibutuhkan oleh masyarakat, hal ini dapat ditinjau dari permohoan akad murabahah yang telah dibantu pendanaanya oleh bank desa.

Berdasarkan ketentuan Fatwa DSN MUI kedua dalam praktiknya di bank desa Pengalangan sesuai dengan ketentuan. Hal ini dibuktikan ketika nasabah mengajukan permohonan pembiayaan dengan akad murabahah, maka bank desa melakukan analisis terkait pengajuan barang yang dibutuhkan. Jika bank desa telah menyetujui, nasabah yang mengajukan permohonan dapat bertindak selaku wakil dari bank desa untuk melakukan pembelian barang yang dibutuhkan. Ketika nasabah menjalankan akad murabahah ini dapat secara berdampingan dengan adanya penerapan akad wakalah yang disepakati oleh kedua pihak yaitu pemberi kuasa ialah bank desa dan penerima kuasa ialah nasabah bank desa. Sehingga, penerapan akad murabahah pada bank desa yang mengalami keterbatasan sumber daya manusia untuk berinteraksi secara langsung dapat diwakilkan oleh nasabah yang mengajukan permohonan atas dasar kesepakatan akad wakalah.

Pada ketentuan ketiga, dalam operasionalnya akad murabahah memperbolehkan adanya jaminan dari nasabah untuk bank desa digunakan jika nasabah tidak mampu melunasi angsuran yang telah disepakti. Pada ketentuan keempat menjelaskan bahwa ketika nasabah menjual barang yang dibeli menggunakan kesepakatan akad murbahah kepada pihak ketiga, maka dari itu nasabah tetap memiliki kewajiban untuk melunasi angsuran yang masih ditagihkan oleh bank desa walaupun nasabah mengalami kerugian. Berdasarkan ketentuan Fatwa DSN MUI kelima yaitu dalam praktiknya di bank desa Pengalangan sesuai dengan ketentuan. Sebagaimana nasabah pada bank desa sebagian besar tidak pernah melakukan penundaan dalam membayar angsuran, tetapi tidak menutup kemungkinan terjadinya kredit macet atau gagal bayar dari nasabah. Pemaparan tersebut diperkuat oleh penelitian dari Putri \& Kusumaningtias (2020) bahwa kredit macet atau dapat diartikan sebagai pembiayaan bermasalahan ialah suatu pembiyaan yang terjadi ketika nasabah tidak melakukan pelunasan hingga waktu jatuh tempo. Ketentuan keenam, bank desa telah melakukan sesuai dengan Fatwa DSN MUI. Selama ini bank desa jika menghadapi kredit macet, maka melakukan pendekatan kepada nasabah untuk mengetahui kendala yang terjadi pada nasabah, jika tetap melebihi batas waktu yang ditentukan pengurus BUMDes memberikan surat pemberitahuan kepada nasabah sebanyak 3 kali.

Dengan kondisi transaksi akad murabahah yang terjadi pada bank desa belum sepenuhnya sesuai dengan peraturan yang berlaku, maka peneliti dapat melakukan evaluasi berupa adanya ketentuan atau batasan pengajuan akad murabahah ini diperuntukan pembiayaan modal kerja, sehingga bank desa dapat menentukan barang-barang kebutuhan yang sesuai dan memulai untuk menjalani kerja sama dengan penyedia barang.

Penerapan akad mudharabah pada bank desa belum sesuai dengan Fatwa DSN MUI yang memiliki beberapa ketentuan berikut ini, 1) akad mudharabah ialah akad yang diterapakan untuk kesepakatan kerja sama dalam suatu usaha dengan melibatkan kedua pihak yaitu pemilik usaha atau pengelola dengan penyedia modal. 2) terdapat empat jenis akad mudharabah yaitu, akad mudharabah-muqayyadah, mudharabah-muthlaqah, 
mudharabah-mustarakah, mudharabah-musyarakah. Setiap bentuk dari akad mudharabah memiliki pengertian yang berbeda-beda. 3) dalam melaksanakan akad mudharabah, penyampaian kesepakatan akad wajib dengan tegas, mudah dipahami, dan jelas sehingga kedua pihak dapat menerima dengan baik, serta kesepakatan akad dapat disampaikan secara lisan, tulisan, maupun isyarat menggunakan media elektronik. 4) pihak pemberi modal wajib menyiapkan modal yang dibutuhkan oleh pengelola dana, sedangkan pihak pengelola dana wajib memiliki kemampuan dan keberanian dalam menjalankan usaha untuk mendapatkan keuntungan. 5) modal usaha yang diberikan kepada pemilik usaha atau pengelola dana tidak diperbolehkan dana dari piutang. Modal usaha dapat diberikan dalam bentuk uang atau barang, jika uang dapat secara tunai maupun tidak sesuai kesepakatan kedua pihak, menggunakan jenis mata uang yang telah disepakati, serta saat akad menjelaskan secara tegas nominal modal usaha yang diberikan. 6) pembagian keuntungan sesuai dengan kesepakatan saat akad oleh kedua pihak, tanpa menggunakan besaran nominal atau presentase untuk menentukan pembagian. 7) jenis usaha yang didirikan wajib sesuai dengan syariat Islam dan tidak mengandung barang dagangan yang diharamkan. Tidak boleh menggunakan nama usaha secara kepemilikan individu, tetapi menggunakan nama entitas. Pengelola modal dapat memberikan sumbangan dan meminjamkan dana dari usaha atas persetujuan dari pihak penyedia modal. 8) jika terjadi kerugian yang tidak disengaja, maka ditanggung oleh pemberi modal. Tetapi bila kerugian terjadi karena kesalahan pengelola dana, maka ditanggung oleh pengelola dana. Kedua pihak yang bersangkutan dalam kesepakatan akad mudharabah, jika mengalami pertikaian dan tidak dapat diselesaikan secara musyawarah maka permasalahan diselesaikan dengan lembaga penyelesaian sengketa.

Akad mudharabah juga diatur dalam PSAK 105 mengenai ketentuan dalam pengakuan, pengukuran, penyajian, dan pengungkapan. Dalam penerapan pengakuan dan pengukuran bank desa sesuai dengan SAK Syariah yaitu memberikan pengakuan sesuai produk atau jenis akad yang diterapkan serta pengukuran nominal yang sesuai dengan total terjadinya transaksi di bank desa pada laporan neraca. Tetapi untuk penyajian dan pengungkapan belum adanya pelaporan dari bank desa, sehingga SAK Syariah belum sepenuhnya diterapkan.

Berdasarkan informasi yang didapatkan oleh peneliti bahwa penerapan BUMDes sebagian sesuai dengan Fatwa DSN MUI, tetapi terdapat sedikit penyimpangan dari beberapa hal yang perlu diluruskan dengan melakukan evaluasi dan memberikan solusi untuk masa yang akan datang. Kesesuaian dan penyimpangan yang terjadi dapat diperjelas dengan pemaparan berikut ini:

Pertama, akad qardh ini diterapkan untuk memberikan bantuan berupa pembiayaan kepada nasabah bank desa yang memerlukan. Dalam operasional bank desa Pengalangan Sejahtera, akad qardh diterapkan pada seluruh kegiatan yang bertujuan untuk membantu nasabah bank desa bangkit dari kesulitan ekonomi seperti memenuhi kebutuhan rumah tangga. Pihak nasabah bank desa jika telah menyetujui kesepakatan akad, maka dapat melakukan pemberian pembiayaan sebesar jumlah pokok yang telah disepakati. Selama ini nasabah bank desa melakukan pelunasan pembiayaan selalu tepat waktu sesuai dengan ketentuan yang diberikan. Pengenaan biaya administrasi yang ditentukan bank desa termasuk beban untuk nasabah, selanjutnya jika pihak nasabah tidak dapat melakukan pengembalian dana wajib melakukan perpanjangan dengan masa waktu yang disepakati.

Kedua, ketentuan sanksi jika nasabah tidak melunasi kewajiban yang harus dibayarkan maka wajib menerima konsekuensi yang diberikan oleh pengurus BUMDes. Konsekuensi dapat berupa barang jaminan yang diberikan kepada bank desa, jika tidak mencukupi nasabah berkewajiban untuk memenuhi kewajibann yang ditangguhkan. Ketiga, pada BUMDes Pengalangan Sejahtera dana yang diberikan bersumber dari modal bank desa dan keuntungan yang didapatkan. Keempat, jika terjadinya permasalahan yang tidak dapat diselesaikan dengan musyawarah, maka pada tahap akhir pihak yang bersangkutan melaksanakan penyelesaian melalui Badan Arbitrasi Syariah. 
Menurut Fatwa DSN MUI mengenai akad qardh, terdapat penyimpangan pada penerapan infaq diawal kesepakatan itu tidak diperbolehkan. Dikarenakan infaq bersifat sukarela yang dapat diberikan kepada bank desa saat nasabah telah melunasi pembiayaannya, tetapi jika infaq di tentukan jumlah presentase nya dan diberikan saat awal kesepakatan maka dapat dikatakan sebagai riba qardh. Selanjutnya, penyimpangan pada akad qardh yaitu adanya jaminan yang wajib diberikan oleh nasabah kepada bank desa. Jaminan tersebut dikenakan biaya sewa sebesar $1 \%$ oleh bank desa, sehingga adanya dua akad yang diterapkan secara bersamaan untuk mengambil keuntungan dari akad qard. Dari penyimpangan yang terjadi maka, peneliti memberikan solusi untuk penerapan akad qardh pada bank desa dapat diterapkan untuk kebutuhan pembiayaan konsumtif berupa non produk, tanpa adanya pengenaan infaq di awal kesepakatan. Tetapi jika nasabah bank desa secara ikhlas ingin memberikan infaq diperbolehkan sekaligus di akhir pengembalian dana yang diberikan oleh bank desa. Jaminan yang diterapkan oleh bank desa untuk mendapatkan keuntungan dari akad qardh, tidak diperbolehkan dikenakan adanya presentase biaya yang wajib dibayarkan oleh nasabah karena akad qardh tidak memberikan ketentuan diperkenankannya mendapatkan imbal balik dari pembiayaan yang telah diberikan.

Model penerapan yang diajukan oleh peneliti ini dikategorikan sesuai produk - produk bank desa yang tersedia serta adanya pembedaan pembiayaan produktif dan konsumtif. Selanjutnya, dari pembiayaan produktif peneliti memberikan usulan dengan adanya pembagian pembiayaan modal kerja dan pembiayaan kerja sama. Pembiayaan modal kerja ini diterapkan pada akad murabahah dengan harapan untuk kedepannya bank desa dapat memiliki ketentuan pendanaan barang yang diajukan oleh nasabah serta terciptanya hubungan kerja sama antara bank desa dengan pihak penyedia barang.

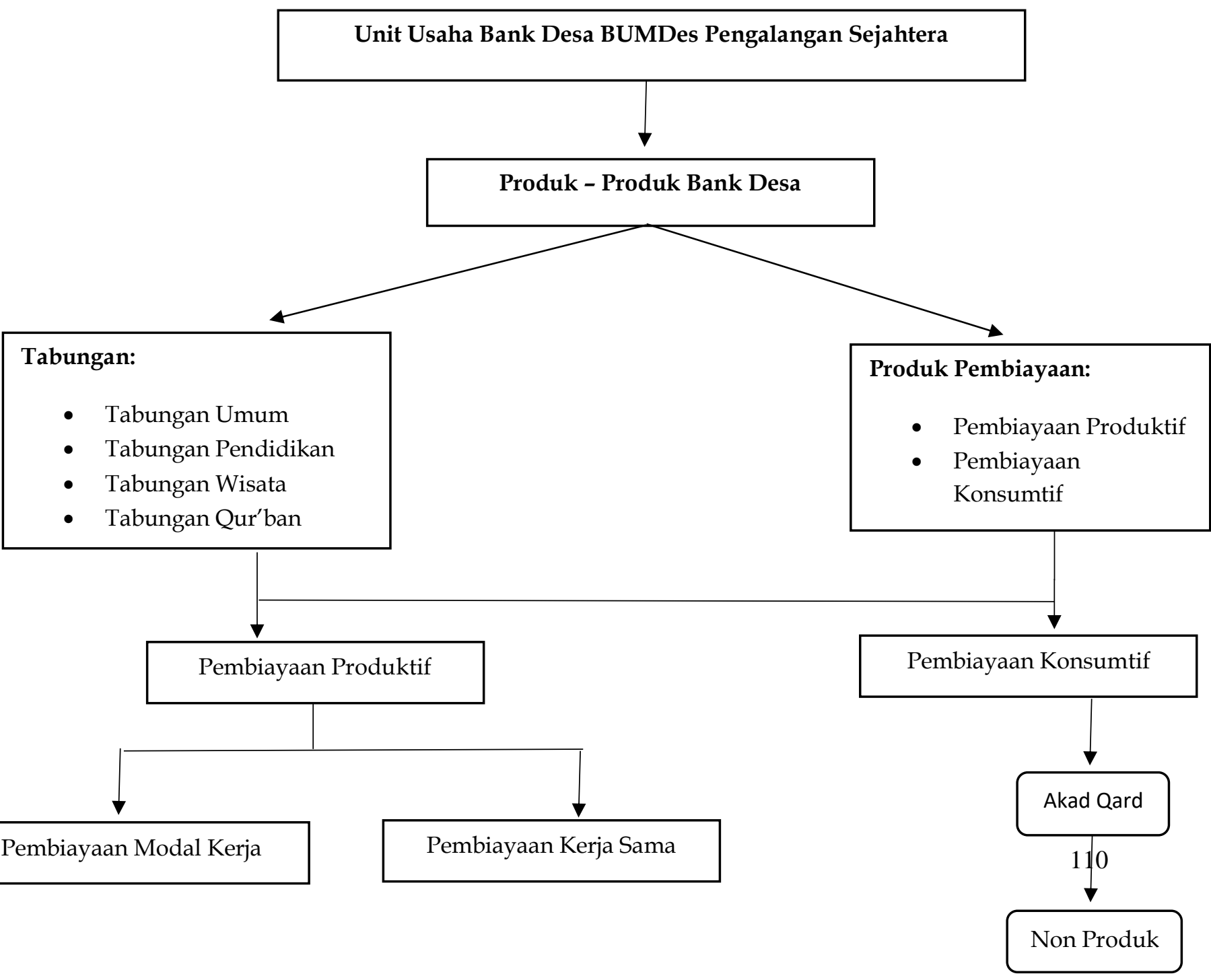



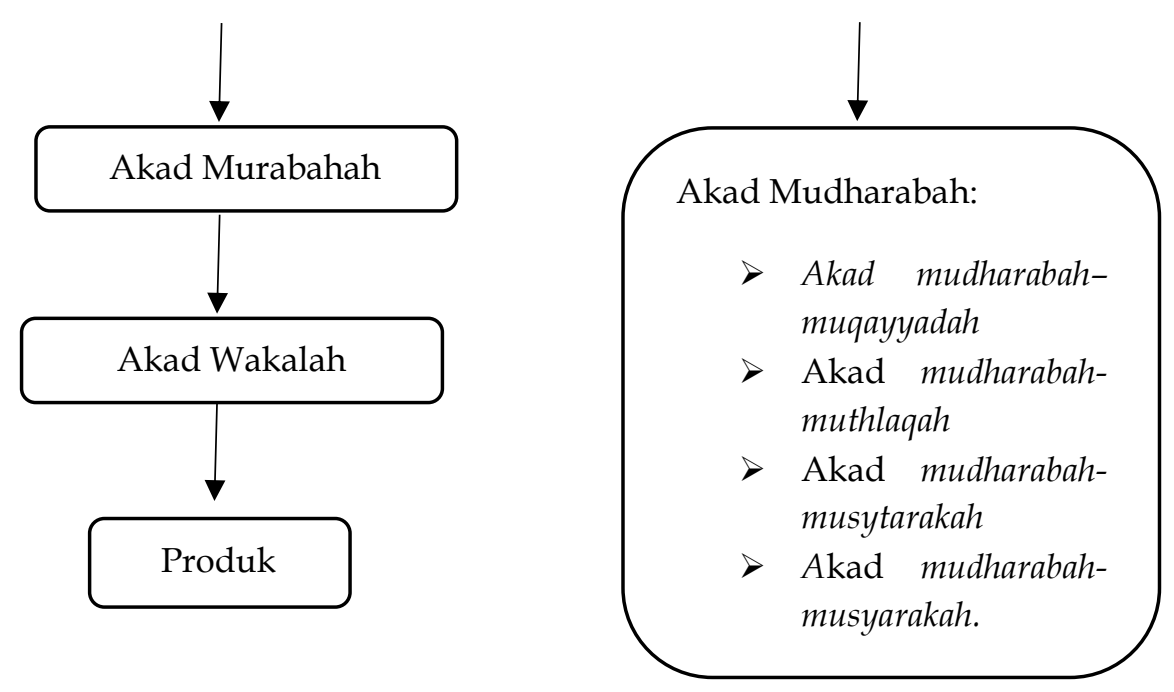

\section{Gambar 1. Model Penerapan Akad Transaksi Syariah}

Berdasarkan Gambar 1 dapat dijelaskan bahwa akad mudharabah pada bank desa dapat diterapkan untuk pembiayaan kerja sama yang khusus untuk membantu nasabah bank desa dalam menjalankan usahanya. Tidak seperti sekarang ini akad mudharabah diterapkan untuk jenis tabungan maka, di hasil penelitian diungkapkan bahwa adanya jenis mudharabah umum, pendidikan, dan qur'ban. Hal ini tidak sesuai dengan peraturan penerapan akad mudharabah yang sesungguhnya. Sedangkan pada pembiayaan konsumtif bank desa menyediakan adanya akad qardh, dalam pelaksanaanya akad ini dapat digunakan atas dasar kepedulian dan untuk kebutuhan sosial non produk. Dari berbagai macam penyimpangan yang terjadi pada masing-masing akad yang telah di terapakan, maka peneliti mengajukan skema untuk penerapan produk - produk akad syariah pada bank desa sesuai dengan skema gambar 1.

Pada skema tersebut peneliti memberikan usulan terkait penerapan akad murabahah dapat diterapkan secara bersamaan dengan akad wakalah, hal ini tidak melanggar syariat Islam. Akan tetapi dalam pelaksanaanya pihak penerima kuasa wajib bertangung jawab atas pemberian kuasa yang diberikan, sehingga skema ini dapat menjadi solusi bank desa terkait keterbatasan sumber daya manusia yang rendah. Pada skema pembiayaan kerja sama ini wajib diterapkan kepada nasabah jika mengajukan permohonan pembiayaan ke bank desa untuk kebutuhan usaha yang dimiliki, maka bank desa tidak perlu lagi menggunakan akad qardh untuk memenuhi pembiayaan yang dibutuhkan nasabah untuk usaha dalam bentuk produk.

\section{Simpulan}

Berdasarkan hasil penelitian mengenai "Model Penerapan Akad Transaksi Syariah Pada BUMDes Pengalangan Sejahtera Dalam Masyarakat Pluralisme" sesuai dengan peraturan yang berlaku, peneliti dapat memberikan kesimpulan bahwa:

1. Penerapan akad syariah pada bank desa dengan lingkup masyarakat pluralisme bukan termasuk halangan bagi pengurus BUMDes dan masyarakat desa. Hal ini termasuk tantangan baru bagi seluruh pengurus BUMDes untuk mengenalkan transaksi keuangan syariah agar dalam operasionalnya BUMDes dapat sesuai dengan visi misi yaitu tidak adanya riba dan memberikan kemudahan nasabah dalam proses pengajuan pembiayaan produk-produk syariah di bank desa. 
2. Dalam praktiknya produk tabungan di bank desa memiliki prinsip yang berbeda, yaitu seluruh nasabah baru yang membuka rekening tabungan menggunakan kesepakatan akad mudharabah umum. Hal ini terjadi dikarenakan bank desa menganggap bahwa dana yang dititipkan oleh nasabah sepenuhnya untuk kegiatan usaha sehingga ketika nasabah mengajukan permohonan akad mudharabah memiliki cadangan dana di bank desa tersebut. Dari permasalahan tersebut peneliti memberikan model penerapan bahwa untuk masa yang akan datang produk tabungan bank desa dapat sesuai dengan akad wadi'ah yang semestinya bank desa terapkan untuk kegiatan menabung, akad wadi'ah ini juga dapat digunakan dalam hal menabung untuk umum, pendidikan, qur'ban, dan wisata.

3. Produk - produk pembiayaan yang diterapkan oleh bank desa ialah akad qardh dan akad murabahah. Dalam penerapannya terdapat kesesuaian dan juga beberapa penyimpangan yang tidak sesuai dengan Fatwa DSN MUI dan SAK Syariah. Kesesuaian terletak pada akad murabahah bahwa bank desa telah menerapkan adanya margin keuntungan dari kesepakatan kedua pihak antara bank desa dan nasabah yang mengajukan. Jika penyimpang yang terjadi yaitu ketika proses pengajuan barang secara sepenuhnya bank desa memberikan kepercayaan kepada nasabah untuk membeli, dengan hal ini maka bank desa tidak dapat secara langsung mengetahui spesifikasi serta harga asli perolehan. Sedangkan pada akad qardh terjadi penyimpangan bahwa nasabah dikenakan biaya infaq di awal kesepakatan akad. Hal ini tidak diperbolehkan karena infaq bersifat sukarela, jika diawal kesepakatan telah ditentukan presentasenya maka termasuk dalam riba.

4. Dengan permasalahan yang terjadi dilapangan, maka peneliti memberikan model penerapan adanya tiga pembagian pembiayaan yaitu, pembiayaan produktif dan pembiayaan konsumtif. Pada pembiayaan produktif terdapat pembiayaan model kerja dan pembiayaan kerja sama.

Peneliti memberikan saran untuk hasil penelitian ini agar dapat berguna untuk peneliti selanjutnya yaitu,

1. Alangkah baiknya BUMDes Pengalangan Sejahtera tidak menerapkan akad qardh sebagai produk pembiayaan yang mengharapkan adanya keuntungan, dikarenakan akad qardh diterapkan dengan asas sosial yang membantu dengan memberikan keringanan untuk nasabah.

2. Keuntungan yang didapatkan oleh BUMDes dapat melalui pembiyaan akad murabahah, akad ijarah, dan akad mudharabah. Dengan mendapatkan keuntungan semaksimal mungkin, tetapi tidak lupa memperhatikan syariat Islam dan kondisi dari nasabah bank desa.

3. Dalam penerapan pembukaan rekening tabungan baru, bank desa dapat memberikan informasi kepada nasabah dengan kesepakatan akad wadi'ah yang sesuai dengan peraturan berlaku untuk melakukan simpan dan pinjam dana.

Bagi peneliti selanjutnya dapat melakukan penelitian terkait mengkaji dari awal pengakuan, pengukuran, penyajian, dan pengungkapan secara lengkap dari laporan keuangan BUMDes. Sehingga hasil dan pembahasan penelitian yang diberikan dapat secara lengkap disajikan berdasarkan SAK Syariah. Serta peneliti selanjutnya dapat melakukan penelitian berupa sistem informasi akuntansi yang menggunakan objek penelitian berupa moblie banking dari bank desa sehingga dapat mengetahui pengendalian internal BUMDes.

\section{Daftar Pustaka}

Febryani, H., Nurmalia, R., Lesmana, I. M. I., Ulantari, N. K. W., Dewi, D. P. Y. P., \& Rizky, N. (2019). Keberadaan Badan Usaha Milik Desa (Bumdes) Sebagai Penguatan Ekonomi Desa Abiantuwung. Jurnal Ilmiah Akuntansi Dan Humanika, 8(1), 95-103. 
https://doi.org/10.23887/jinah.v8i1.19865

Irawati, D., \& Martanti, D. E. (2017). Transparasi Pengelolaan Laporan Keuangan BUMDes terhadap Pelaporan Aset Desa (Studi Fenomenologi Pada BUMDes Desa Karangbendo Kec Ponggok Kab Blitar). Prosiding Seminar Nasional Dan Call For Paper Ekonomi Dan Bisnis, 2017, 41-51.

Ma'arif, S. (2018). PENDIDIKAN ISLAM PLURALIS Menampilkan Wajah Islam Toleran dalam Pendidikan Islam. TOLERANSI: Media Ilmiah Komunikasi Umat Beragama, 10(2), 176. https://doi.org/10.24014/trs.v10i2.7084

Muhayatsyah, A. (2019). Analisis Penerapan Transaksi Ijarah Dan Al Ijarah Al Muntahiya Bit Tamlik Pada Bank Syariah. JESKape, 3 No. 2, 1-18.

Nugrahani, F. (2014). Metode Penelitian Kualitatif dalam Penelitian Pendidikan Bahasa. 1(1), 305. http://ejournal.usd.ac.id/index.php/LLT\%0Ahttp://jurnal.untan.ac.id/index.php/jpdpb/article/view File/11345/10753\%0Ahttp://dx.doi.org/10.1016/j.sbspro.2015.04.758\%0Awww.iosrjourna ls.org

Nugrahaningsih, Putri, Falikhatun,Winarna, J. (2016). Optimalisasi Dana Desa Dengan Pengembangan Badan Usaha Milik Desa Menuju Desa Mandiri. Jurnal Akuntansi Dan Bisnis, 16(1), 37-45.

Nurohman, Yulfan Arif, Qurniawati, R. S. (2019). Dana Desa Dalam Peningkatan Kesejahteraan Masyarakat Pada Desa Wisata Menggoro. Jurnal Magisma, 7(1), 35-43.

Pramesty, A. O. (2020). PERANCANGAN PENGELOLAAN BADAN USAHA MILIK DESA BERBASIS SYARI' AH. 1(2).

Pratiwi, Dini, Nawawi, M. Kholil, K. (2015). IMPLEMENTASI FATWA DSN MUI NO: 04/DSN-MUI/IV/200O TENTANG MURABAHAH PADA PEMBIAYAAN KONSUMTIF (STUDI KASUS BNI SYARIAH CABANG BOGOR) Dini Pratiwi. 6(1).

Putri, S., \& Kusumaningtias, R. (2020). FAKTOR-FAKTOR YANG MEMENGARUHI PEMBIAYAAN BERMASALAH PADA BANK UMUM SYARIAH DI INDONESIA. 8(2).

Puwari, A. (2010). MENYIBAK PELAPORAN ASET BERSEJARAH BERDASARKAN PSAP NO. 07 TAHUN 2010. Jurnal Ilmiah Ilmu-Ilmu Ekonomi, 9, 1.

Wildan, M. (2018). SISTEM EKONOMI ISLAM SIMBOL KESEJAHTERAAN MASYARAKAT. Ekonomi Islam, 6(2), 267-286. 